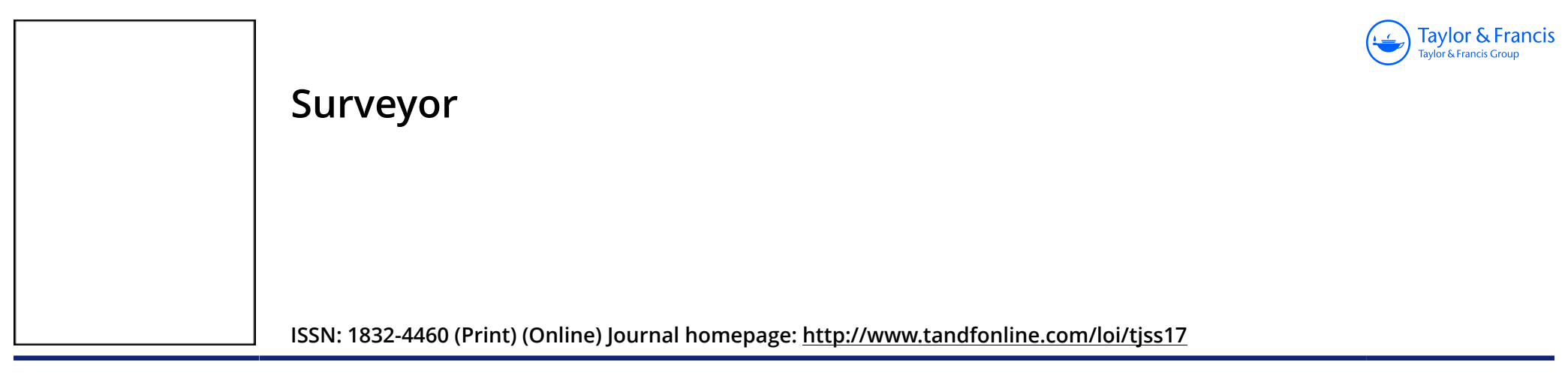

\title{
Pioneer Surveyors of New South Wales
}

\section{John Weigarth}

To cite this article: John Weigarth (1919) Pioneer Surveyors of New South Wales, Surveyor, 32:1, 16-23, DOI: 10.1080/18324460.1919.10439452

To link to this article: http://dx.doi.org/10.1080/18324460.1919.10439452

曲 Published online: 01 Aug 2012.

Submit your article to this journal

LII Article views: 1

Q View related articles $\sqsubset$ 
It is very desirable that all the observatories keep the same time as exactly as possible, in order to class the meteorologic phenomena to note accurately the occurrence of earthquakes and to study their propagation, etc. In this case we measure rather the duration than determine the absolute time, and we can arrive at a greater precision if the clocks are in accord.

$$
\text { E. P. COTTON, }
$$

Late Commissioner of I.ands and Director of Surveys, Nigeria.

\title{
Pioneer Surveyors of New South Wales.
}

\author{
By John WeINGarth, L.S. \\ GEORGE WILLIAM EVANS \\ (Continued).
}

The following is tak.n from the Historical Records referring to the Journal of Assistant Surveyor Evans. :-

" G. W. Evans and his party of four men left Bathurst on the I3th of May, 1815, and encamped in the evening in the neighbourhood of Perth.* One day was lost in searching for the horses which had strayed, and on the x6th he reached the centre of three peaks now known as the Three Brother. Evans named these hills, Antill's Peak, Mount Macquarie, and Maclaine's Peak.

" On the 22nd, he discovered and named Mount Lachlan, about three miles south east of Carcoar. He camped four miles south of this peak; and on the following day he travelled west for four miles, when in the distance he sighted the Canobolas, and named the peak Jamison's Table Mountain. On the $2 \psi^{\text {th }}$, he discovered Limestone Creek at a point a little north of west from Lyndhurst. He followed the creek down to its junction with the Belabula river, which he named Lewis' Creek. On the 25th, he ascended the Sugarioaf, which he named Mount Lewin. On the 26th, he passed Licking Hole Creek, and on the following day he discovered the Lachlan River between North Logan and Cowra. On Sunday, the 28th, he allowed three of his men to rest in camp, and with the fourth man he ascended the River for six miles to the neighbourhood of Cowra, and named the river flats Oxley's Plains. During the next four days, he traced the river down to its junction with Mandagery Creek, which he named Byrne's Creek.

"From this point, he was compelled to commence his return journey on the and of June, I8I5, and he arrived at Bathurst ten days later."

\footnotetext{
* Now Perthville.
} 
Evans returned to Hobart probably after drawing the plan of his survey in Sydney.

$\mathrm{He}$ was again recalled to Sydney and in $\mathrm{I} 8 \mathrm{I} / \mathrm{7}$ he accompanied Oxley in his explorations down the Lachlan River and back to Bathurst and in 1818 down the Macquarie and north easterly through Liverpool Plains to Port Macquarie-Evans was second in command, and no doubt did all the surveying and probably was actually the leader as stated in his memorial to Governor Brisbane.

From Journals of two expeditions into the interior of New South Wales in the years, 1817,1818 , by John Oxley, Surveyor-General, published in 1820 , I take the following: "On May Ist, I8I7, commenced the survey of the river (the Lachlan), from this point (Byrne's Creek)." According to the introduction to that book, apparently this survey was made with Kater's Pocket Compass, which was used on a Tripod like a circumferentor (see the view of Liverpool Plains drawn from sketch by Evans on page 275 of Oxley's Journal).

The small theodolite was probably used for observations for latitude, it would be an interesting relic. I have not seen any plan of the survey but the map in Oxley's Book although drawn to a small scale shows traverses.*

It was while on the trip in I8I8 that Oxley sent Evans to the north when he found the Castlereagh River, a copy of Evans' diary on that excursion is in Oxley's Book from which I make a copy.

Oxley writes :-

"July Ist, $\mathrm{I} 8 \mathrm{I} 8$, it was determined, that during my absence (tracing the Macquarie River further west), Mr. Evans should proceed to the north east from fifty to sixty miles, and return upon a more northerly course, in order that we might be prepared against any difficulties that might occur in the first stages of a journey to the north east coast."

On July 7 th, Oxley returned up the river to Mount Harris, Mr. Evans had not yet set out on his journey.

"July 8th, Mr. Evans set forward to the north east, taking with. him eight or ten days provisions."

July 18 , "In the evening Mr. Evans returned, after an interesting though disagreeable journey. His horses were completely worn out by the difficulties of the country they had travelled over. His report, which I shall give at length, decided me as to the steps' that were now to be pursued, and I determined in making nearly an easterly course to the river he had discovered, and which was now honoured with the name of Lord Castlereagh."

Diary of Mr. Evans, Deputy Surveyor-General, from the 8th, to the I8th of July, I8I8.

Wednesday, July 8.--Left Mount Harris about nine o'clock. For six miles the country tolerably good; afterwards, to the end of my day's journey, it was alternately acacia pendula scrubs, and cypress bushes; the soil light, and full of holes ; abundance of water,

* The original plan is in the Lands Department, probably drawn by Oxley as they travelled. 
but, latterly, no grass. In the evening halted on the bank of a gully, having gone about twelve miles. Mount Harris bearing S. $35^{\circ} \mathrm{W}$.

July 9.-Set forward at eight o'clock, and continued travelling until five in the afternoon, chiefly through very thick brushes, consisting of various shrubs, with casuarina and dwarf box trees; the country nearly a marsh and almost impassable, so much so, that I had great difficulty in keeping my course, being the greater part of the day up to our knees in water.

I estimate my distance this day to be about fifteen miles, on a north east course.

July 10.- The country worse than yesterday, being exceedingly low and marshy, with many thick scrubs. About eleven o'clock it opened, being more thinly clothed with the acacia pendula : having travelled about ten miles, we arrived on the borders of a large apparent plain on which I had proceeded about two miles, when we were suddenly stopped by deep water among reeds ; from hence I could distinctly see Arbuthnot's Range, the north end of which bore N. 10I ${ }^{\circ}$, and the other part connected by a low range bore from N. I08 to N. II $2^{\circ}$.

The country from the north west to north east was open with the horizon, being covered with water and reeds, as far as the eye could distinguish; we saw immense numbers of wild ducks, many black swans, pelicans, and birds resembling the sea gannet: I altered my course to east, and shortly afterwards to south east.

I estimate the distance travelled this day to be eighteen miles. Being rather late, we were much at a loss to find a place dry enough to sleep on : the north end of Arbuthnot's Range bore N. $98^{\circ}$.

July II.--Finding our efforts to travel in any direction north of east useless, I altered my course for the north end of Arbuthnot's Range. The country continuing nearly as yesterday, brushes and marshes alternately, having gone about twelve miles, the last quarter of a mile of which was an almost imperceptible rise above the general level, I came to the edge of a river, the stream of which was thirty or forty yards wide, but the bed nearly one hundred yards, the banks being eight or nine feet high : I forded it in the middle of a very long reach bearing north and south, the stream clear, and running gently from the south, about three feet deep over a fine sandy bottom. After crossing this river, I proceeded onwards about fou miles, and halted on the edge of a brush, having travelled sixteen or seventeen miles.

July 12.-After proceeding about four miles, we crossed a small stream from the south-east; the country perfectly level, not a perceptible rise in any direction, save Arbuthnot's Range, the space travelled over to-day was a complete marsh, the soil good, being clearly alluvial. It will be impossible for heavy loaded horses to walk over the country traversed by us these last three days, the trouble we have had is more than can well be imagined. Travelled fifteen miles.

July 13.-A very cold morning, set off at sunrise : at the sixth mile arrived on an open plain, over which was rather better travelling than we had latterly experienced. Finding it unlikely that we should reach the range, at least in time to view the country from it, 
I thought it best, as I had no time to spare, to keep more southerly for a lofty eminence about two miles distant, and apparently of easy ascent; this mount afforded me a most extensive prospect. The south extreme of Arbuthnot's Range bore south, the north extreme N. $20^{\circ} \mathrm{E}$, then trends more easterly. Westerly of the hill on which I stood and the range, the country is a perfect level, without the slightest apparent rise or inequality ; what I could see of the country to the south-east, appeared to be very broken and rugged, detached rocks projecting like pillars and pyramids, in various parts of the ranges; there was a number of native fires about the base of the range, and we saw plenty of Kangaroos, for the first time since quitting Mount Harris : I also this day shot a new species of pigeon. The distance travelled, I suppose sixteen or seventeen miles.

July I4.--Set forward on my return to the tents in a south-west direction, and passed, for four or five miles, through a good open forest country, abounding with Kangaroos : after passing that, the country altered for the worse, becoming low and wet : at twelve miles, we crossed $a$ chain of ponds leading to the north.

Last evening we suspected that we had been watched by the Natives. I saw some of them, and our resting place was surrounded by their smokes; they however did not attempt to molest us. Stopped in an acacia pendula brush, having travelled about twenty miles.

July 15.-It came on to rain in the night, and continued all this day. Our journey was dreadfully bad and marshy; yet on the whole the country had a better aspect, not being so much overrun with the plant called rhagodia as usual. On my traok out, plains, brushes, indeed almost the entire surface was covered with it, until within a few miles of Arbuthnot's Range. After going about three miles, we again fell in with and forded the river crossed on the IIth instant: it was here not quite so wide as when first seen, but deeper. Halted, having gone about ten miles.

July I6.-I altered my course from south-west to west 80 degrees south, and had an extremely tedious and unpleasant day's journey, through a wet and dreary country; continued rain. Travelled fifteen miles.

July I8.- Arrived at the hut about one o'clock, p.m., having travelled yesterday and to-day about thirty-seven miles.

(Signed) G. W. EVANS.

Oxley writes :-

July 25th, "Since Mr. Evans recrossed (on his previous trip) the river (the Castlereagh), we had no rain in our immediate neighbourhood sufficient to cause the sudden rise, which therefore must be attributed to heavy falls among the mountains to the east, southeast from whence I have no doubt it derives its course. It was most providential that Mr. Evans and his companions crossed the river when they did ; a single day might have proved fatal to them."

On August 26t $\mathrm{h}$ they found the Liverpool Plains. 
On September 26th discovered the Hastings River, which they followed reaching Port Macquarie on the Ioth October, shortly afterwards they started southerly along the coast towards Newcastle, and on October 3Ist the following incident occurred : Dr. Harris and Mr. Evans had gone to bathe near the point and within 150 yards of the tent-Mr. Evans had already bathed and had began to dress himself, when four Natives, whom we recognised as being among those whom we had treated so kindly yesterday, made their appearance with their spears in their hands, in the attitude of throwing them from the cliffs above. There was scarcely time to parley with them when a spear was thrown at Mr. Evans, Dr. Harris having leaped down the rock into the sea and escaped to the tent under its shelter, the spear fortunately missed Mr. Evans, and he likewise escaped with the loss of his clothes, by following the doctor's example. On the alarm being given they were pursued, but they had disappeared among the brush on the hill while the horses were being collected and I was sitting in the tent with Dr. Harris and Mr. Evans writing this journal, a shower of spears from the height above was thrown at the tent, one of which passed directly over my shoulder and entered the ground at my feet, etc."

On Nov. Ist they arrived at Port Stephens.

In this district Grimes had the trouble with the Natives in 1795 (see my paper on Grimes-in The Surveyor of February, I9I7. Vol. XXX. No. I).

On Nov. $5^{\text {th }}$ to arrange for the relief of the main party Mr. Evans left for Newcastle (thirty-six miles), in the small boat they had found further up the coast, and arrived there in the afternoon. The Commandant (Captain Wallis) immediately sent a large boat with food and the other members of the expedition were brought to Newcastle.

In his report to Governor Macquarie, Oxley writes :-

"The general merits of Mr. Evans are so well known to your Excellency, that it will here be sufficient to observe that by his zealous attention to every point that could facilitate the progress of the expedition, he has endeavoured to deserve a continuance of your Excellency's approbation."

Evans was practically the leader and proved himself a good explorer, probably if he had not been in the party the expedition would have been a failure.

On their trip down the coast from Port Macquarie they crossed the mouth of the Manning River without knowing it was a River; in December, I820, Oxley went inside the Macleay River from the sea, and apparently did not know it was a River as he refers to it as an inlet, and as he had discovered one of the heads of the Macleay at Apsley Falls near Walcha, he was the discoverer of the head and mouth of that river.

It is rather surprising that Evans did not notice the river, but it might be explained that at this time the party was in rather awkward circumstances, and was hurrying back as fast as they could to escape disaster. 
In November, I8I8, Evans returned to Sydney from that trip. I cannot find out any particulars as to his stay in Sydney, but it is probable he devoted some time to compiling a plan of the journey just completed, although as he returned in 1818 to Hobart he may not have finished it.

He apparently did a lot of exploring in Tasmania as stated by him in his memorials, and measured a number of grants. The Surveyor-General of Tasmania was kind enough to send me the following letter ; it is unfortunate that there are no Field Books of his sur'vey along the coast south of Port Jackson, as the names of some of the headlands and bays may have been noted :-

$$
\begin{gathered}
\text { Department of Lands and Surveys, } \\
\text { Crown Lands Office, } \\
\text { Sir, Hobart, roth April, I9I8. }
\end{gathered}
$$

Re George Wi. Evans, one time Surveyor-General, Tasmania.

In reply to your letter of the $4^{\text {th }}$ instant asking for particulars of the above gentleman, I have to inform you that he became Deputy Surveyor-General in Tasmania-under Mr. John Oxley of New South Wales-about the year I8I6, and held, in conjunction with that position, those of Inspector of Roads and Bridges and Collector of Quit Rents for Crown Lands. Mr. Evans was brought into close relation with Lieut.-Governor Sorell-April, I8I7 to May, I824-in connection with surveys of grants, some I40 of which were issued during the last five months of Lieut.-Governor's Sorell's administration. The Lieut.-Governor's numerous letters of instruction are couched in terms indicative of cordial relations between himself and Mr. Evans.

Though during his tenure of office Mr. Evans was not afforded an opportunity of acquiring prominence in the annals of his Department, he rendered his adopted country conspicuous service by publishing in London in 1822 a "History and Description of the present state of Van Diemen's Land," a work which attracted favourable attention in England with a correspondingly favourable effect upon immigration. Mr. Evans retired from the Surveyor-Generalship in I825, and was succeeded by Mr. Edward Dumaresq.

There is evidence that Mr. Evans was engaged on the survey of Hobart in I8II. He published a map of Tasmania in I828, which was regarded as the standard map of the State in its time.

There is, I am afraid, no hope of obtaining any field books of his surveys, but there is a statutory declaration signed by him in Sydney on $5 / 5 / 1834$, in which he is described as late Surveyor-General of Van Diemen's Land, and narrates that he made a fatiguing survey of Macquarie Harbour and the Gordon River. Governor Sorell promised him a grant of land which of course he subsequently obtainer.

I enclose a copy of a letter written by him on roth April, I822, to John Oxley, Surveyor-General of New South Wales, which shows that he was more concerned at that time with administration work than actual surveys. 
His remains are buried in St. John's Churchyard, New Town, near Hobart.

The date at which the title of Deputy Surveyor-General was altered to Surveyor-General is not obtainable here.

I also enclose a copy of a general notice relating to the width of roads and footpaths signed "G. W. Evans, Deputy SurveyorGeneral."

Please let me know if I can do any more to help you in this matter.

Yours faithfully,

E. A. COUNSEL,

Surveyor-General.

John Weingarth, Esq.,

Surveyor, Io Castlereagh Street, SYDNEY.

(Copy.)

Sir,

I beg leave to enclose you copies of a letter which his Honour the Lieut.-Governor transmitted to me, and of my answer thereto. You will see that I have taken the liberty of suggesting some alterations in the proposed new system, from the perfect conviction which I feel that it cannot be carried conveniently into effect in this Island on many accounts, but very particularly in consequence of the general want of water experienced in the interior during the summer months. I have no doubt but that I shall have the advantage of your coincidence in the alterations I have suggested, from your knowledge of the disadvantages attendant here upon the new plan, and I need not say that I shall feel myself much obliged by your expressing to His Excellency the Governor-in-Chief any opinion you may form favourable to the suggestions I have presumed to submit. Indeed, should the plan of square mile locations be determined on, I have no doubt but that a very great majority of them will be wholly without water. You are perfectly aware that we have no natural springs, the soil being so entirely formed of calcareous earth and of so arid a nature that a considerable fall of rain is readily absorbed. Of course I shall do the utmost in my power to lay out the land to the greatest advantage but I hope you will be of opinion (on comparing the plan I have taken the liberty to offer with that of Square mile locations) that by adopting the former, the country will be most fairly and advantageously divided.

I have the honour to remain,

Your very obedient servant, (Sgd.) G. W. EVANS,

Deputy Surveyor-General.

John Oxley, Esq., Surveyor-General. 
(Copy).

PUBLIC NOTICE-Nov. $4^{\text {th, }}$ I824.

The Government and General Orders respecting the width of the Roads throughout the Country having been disregarded in many instances, the Lieutenant-Governor calls the attention of the public to them, and for general information now makes it known that whenever a Public Road is marked out, Thirty Feet will be required as well as eight feet on each side for a footpath, and any person encroaching by buildings or fences must do so on their own responsibility.

By Command,

(Signed) G. W. EVANS,

Deputy Surveyor-General.

\section{L.S. Examination Problems.}

The following Solutions of a Problem recently set in the I...S. Examination have been forwarded by Mr. M. I. Brothers, I..S. :-

In the figure hereunder $B X C$ is a straight line and $B Q R=X P R$ $=90^{\circ} ; B X=C P=1000$ links. From data compute the lengths $B Q, C X$, arc $P Q$, angle $P R Q$ and the area $B C P Q$ fronting on arc $P Q$.

\section{I.}

Draw $P S$, arallel to $C B$; then $B S=C P=B X=$ ro chains $\therefore B \hat{S X}=45^{\circ}$.

Describe a circle on $D P$ as diameter : $O$ is the centre.

Pruduce $S X$ to meet circumference in $T$.

Join $T O$ and produce to meet circum. in $V$.

Since arc $D T$ subtends $45^{\circ}$ at circum., the diameters $T V$ and $D P$ intersect at right angles.

Hence $V \widehat{S} T$ is a right angle.

Now the points $V S X O$ are concyclic.

$\therefore T O \cdot T V=T X \cdot T S=T X(T X+X S)$ 